\title{
Switchgrass (Panicum virgatum L.) Cultivar Adaptation, Biomass Production, and Cellulose Concentration as Affected by Latitude of Origin
}

\author{
Paul G. Jefferson ${ }^{1}$ and W. Paul McCaughey ${ }^{2}$ \\ ${ }^{1}$ Western Beef Development Centre, P.O. Box 1150, Humboldt SK, Canada SOK 2 AO \\ ${ }^{2}$ Agriculture and Agri-Food Canada, 107 Science Place, Saskatoon SK, Canada S7N 0X2 \\ Correspondence should be addressed to Paul G. Jefferson, pjefferson.wbdc@pami.ca
}

Received 29 August 2012; Accepted 2 October 2012

Academic Editors: T. Coffelt, J. Ransom, and B. Trognitz

Copyright () 2012 P. G. Jefferson and W. P. McCaughey. This is an open access article distributed under the Creative Commons Attribution License, which permits unrestricted use, distribution, and reproduction in any medium, provided the original work is properly cited.

\begin{abstract}
Ten cultivars of switchgrass (Panicum virgatum L.) of northern and southern origins that had demonstrated adaptation to North Dakota were evaluated for biomass production, cellulose concentration, and nutritive value in the southern Canadian prairie region: Saskatchewan and Manitoba. In this region, cultivars adapted to northern latitudes present interest for biomass production. Latitude of origin of the cultivars was positively correlated to stand density $(r=0.83, P<0.01)$, biomass production $(r=0.69$, $P<0.01)$, and cellulose $(r=0.84, P<0.01)$, and negatively correlated with organic matter digestibility $(r=-0.86, P<0.01)$ and $\mathrm{N}(r=-0.85, P<0.01)$. Dacotah and ND 3743, the northern origin cultivars, were more persistent in Brandon, MB (94 to $100 \%$ stand density) and exhibited higher cellulose and hemicellulose concentrations than southern cultivars. Southern cultivars produced higher biomass than northern-origin cultivars until they suffered significant stand and biomass decline. Cave-in-Rock, the southern origin cultivar, did not persist in the third year after seeding. However, southern-adapted cultivars exhibited better nutritive value for grazing cattle. We conclude that switchgrass production in the southern Canadian prairie should utilize the USA cultivars from northern latitudes or adapted Canadian cultivars should be developed.
\end{abstract}

\section{Introduction}

Rising world energy demand and government policies to increase secure domestic supplies of energy in North America have created interest in ethanol for automotive fuels. Biomass crops that can be converted to ethanol biofuel by enzymatic digestion and fermentation or thermochemical conversion of plant cellulose and hemicellulose polymers to ethanol in large-scale biorefineries have been identified [1]. Switchgrass (Panicum virgatum L.) is a warm-season (C4) grass species native to the tallgrass prairie region of North America including the southern Canadian prairie. Generally, warm-season grass species can be moved about 300 miles north or 200 miles south of their original location [2]. This grass has been studied for lignocellulosic biomass conversion to fuel-grade ethanol in USA, but the southern
Canadian prairie region is its northern limit of adaptation. Cultivation of switchgrass in this region will require cultivars adapted to northern latitudes. Northern ecotypes have a longer winter dormant period with better winter survival than southern ecotypes when grown at the same latitude [3]. The attributes of switchgrass for a biomass crop include its yield potential, longevity, water use and nutrient use efficiency, and suitability for marginal land. Switchgrass has been reported to produce excellent biomass yield in North Dakota, South Dakota, and Minnesota $[4,5]$ and in southern Quebec [6] but may be limited in the prairie region of Western Canada to sites south of $51^{\circ} \mathrm{N}$ latitude [7]. Also, only one switchgrass cultivar was evaluated in Canada $[7,8]$, but several cultivars have been developed or successfully cultivated in North Dakota, USA [4]. The objective of this research was to evaluate the biomass production, cellulose 
concentration, nutritive value for ruminant livestock, and persistence of a number of USA-adapted switchgrass cultivars at two locations in the southern Canadian prairie region.

\section{Materials and Methods}

2.1. Study Site Description. The experimental sites were Brandon, Manitoba $\left(49^{\circ} 50^{\prime} \mathrm{N}, 99^{\circ} 57^{\prime} \mathrm{W}\right)$ and Swift Current, Saskatchewan $\left(50^{\circ} 16^{\prime} \mathrm{N}, 107^{\circ} 44^{\prime} \mathrm{W}\right)$, Canada. The soil at Brandon was an Orthic Black Chernozem fine sandy loam (sandy, mixed frigid, udorthentic Haploboroll). The soil at Swift Current-dryland site was a Swinton loam, Orthic Brown Chernozem [9] or a fine, mixed, aridic Haploboroll and at Swift Current-irrigated site, it was an alluvial Rego Chernozem (clay to clay loam) [9] or alluvial typic Haplustoll. Seeds of ten switchgrass cultivars were obtained from the USDA NRCS Plant Materials Centre at Bismarck, North Dakota (Table 1). Cultivar descriptions of eight entries and nomenclature of this report can be found in Alderson and Sharp (1994) [10]. The experiment was seeded with $5.9 \mathrm{~kg} \mathrm{ha}^{-1}$ (based on Pure Live Seed (PLS)) on 28 June, 1993 at Swift Current and on 11 August, 1993 at Brandon. Individual plots were 6 rows wide and 1.8 $\times 6 \mathrm{~m}$ at Swift Current and 5 rows wide and $1.5 \times 6 \mathrm{~m}$ at Brandon. Weeds were controlled by hand at Brandon and no herbicides were used at this location. At Swift Current, weeds were controlled in the establishment year by application of Buctril M ( $280 \mathrm{~g} / \mathrm{L}$ bromoxynil (3,5-dibromo4-hydroxybenzonitrile) and $280 \mathrm{~g} / \mathrm{L}$ MCPA (4-chloro-2methyl(phenoxy)acetic acid)) formulated as a emulsifiable concentrate on 9 July, 1993. In 1994, weeds were controlled with application of 2,4-D ((2,4-dichlorophenoxy)acetic acid) and Banvel (Dicamba (3,6-dichloro-2-methoxybenzoic acid)) on 27 April, 1994. Weeds were controlled in 1995 with application of atrazine (6-chloro- $\mathrm{N}-$ ethyl- $\mathrm{N}^{\prime}$-(1methylethyl)-1,3,5-triazine-2,4-diamine) on 11 May, 1995. At Swift Current-irrigation Buctril $\mathrm{M}$ was applied on 12 June, 1996 and atrazine on 25 July, 1996 for weed control. The delayed spring growth initiation by switchgrass resulted in weed invasion and competition from cool-season annual weeds in every growing season at Swift Current at both sites. Foxtail barley (Hordeum jubatum L.) was a frequent weed problem and herbicide control varied from excellent in one year (1995) to poor in the next year (1996). At Swift Currentdryland, crested wheatgrass (Agropyron cristatum L. Gaertn.) was the major weed species and the application of atrazine did not control it.

Weather at Swift Current and Brandon was recorded at standard agrometerological stations within $1-2 \mathrm{~km}$ of the experimental locations (Table 2). Irrigation water was applied at Swift Current-irrigation to increase biomass productivity with $62 \mathrm{~mm}$ on 21 June, $75 \mathrm{~mm}$ on 29 July, $69 \mathrm{~mm} 18$ August, and $75 \mathrm{~mm}$ on 29 August, 1994; $75 \mathrm{~mm}$ on 18 May, $75 \mathrm{~mm}$ on 31 May, $62 \mathrm{~mm}$ on 3 August, $62 \mathrm{~mm}$ on 21 August, and $62 \mathrm{~mm}$ on 13 September, 1995; $75 \mathrm{~mm}$ on 05 June, $62 \mathrm{~mm}$ on 7 August, and $75 \mathrm{~mm}$ on 21 August, 1996. No irrigation was provided at Brandon.
2.2. Data Collection. Seedling emergence was visually evaluated at Brandon on 7 September, 1993 by counting seedlings in randomly located quadrants. Stand density was ocularly estimated as a percentage of soil cover in each plot by 2 to 3 experienced observers. Due to the number of observations between 30 and $70 \%$, it was determined that transformation of stand density data was not required prior to analysis of variance [11].

Sites were sampled in late September or as close as possible to the first frost $\left(-3^{\circ} \mathrm{C}\right)$ of the autumn season. Forage samples were harvested in September during the study years with a flail-type forage harvester from the center $0.61 \mathrm{~m}$ width of each plot at Swift Current. In some plots at Swift Current where plant density of switchgrass was low, hand-clipped samples of switchgrass were harvested from $1 \mathrm{~m}^{2}$ area within each plot. Forage samples at Brandon were harvested in late September of 1995 and early October of 1996 with a flail-type harvester from the center $0.91 \mathrm{~m}$ width with a stubble height of $5 \mathrm{~cm}$. Fresh total plot yield was weighed and recorded. Subsamples were weighed, dried at $60^{\circ} \mathrm{C}$ in a forced-air oven, and reweighed to calculate dry matter (DM). Plot biomass yields were converted to DM biomass yield prior to analysis.

Additional subsamples of biomass from both sites were dried and ground to $1 \mathrm{~mm}$ particle size and forage nutritive value was determined in analytical laboratories at the Agriculture and Agri-Food Canada Semiarid Prairie Agricultural Research Centre in Swift Current. The low biomass production of Trailblazer at Swift Current Site 2 was insufficient for a complete set of analyses on this cultivar. Cellulose and hemicellulose concentrations were determined by standard methods $[12,13]$. In vitro organic matter digestibility (OMD) was determined by modified technique of Tilley and Terry (1963) [14, 15]. Fistulated sheep wethers used for the collection of rumen fluid were fed a bromegrass (Bromus inermis L.)/alfalfa (Medicago sativa L.) hay diet and cared for in accordance with the Canadian Council on Animal Care guidelines [16]. Nitrogen concentration was determined following AOAC (1984) [17]. Phosphorus concentration was colorimetrically determined after the samples had been digested with sulphuric acid [18]. Calcium concentration was determined after a nitricperchloric acid digestion [19].

2.3. Statistical Analysis. Experiments of a randomized complete block design with six replications were established at all three sites. Analysis of variance was determined with JMP software [20]. Biomass data were analyzed as a split-plot in time and space [11] with a mixed model, where replication and its interactions were random effects and cultivars, sites, and years were fixed effects. Due to the large range in biomass production data, this parameter was transformed according to the formula: $Y=\log _{10}$ (Biomass) and the resulting transformed data were analyzed. Biomass production data from each site-year were also analyzed separately as a randomized complete block experiment. The least-square cultivar means for biomass production were backtransformed to the original data scale for presentation. Cellulose concentration 
TABLE 1: Switchgrass cultivars grown for biomass production and cellulosic concentration at Brandon, MB and Swift Current, SK, Canada in 1995 and 1996.

\begin{tabular}{lccc}
\hline Cultivar & Breeding institution $(\mathrm{s}){ }^{\wedge}$ & Year of release & Site of origin \\
\hline Blackwell & KS AES, NRCS Manhattan KS & 1934 & Blackwell, OK \\
Cave-in-Rock & MO AES, NRCS Elsberry MO & 1958 & Cave-in-Rock, IL \\
Dacotah & ARS NRCS Bismarck ND & 1989 \\
Forestburg & ARS NRCS Bismarck ND & Breien, ND \\
Nebraska 28 & NE AES, ARS, NRCS Lincoln NE & 1987 & Forestburg, SD \\
Pathfinder & NE AES, ARS Lincoln NE & 1935 & Holt County, NE \\
Summer & SD AES Brookings SD & 1953 & Sites in NE and KS \\
Sunburst & U. of South Dakota & 1953 & Nebraska City, NE \\
ND 3743 & NRCS Bismarck ND & 1998 & Union County, SD \\
Trailblazer & ARS, U. of Nebraska & - & Upham, ND \\
\hline
\end{tabular}

${ }^{\wedge}$ AES: Agricultural Experiment station; ARS: agriculture Research Service USDA; NRCS: Natural Resource Conservation Service USDA; U. of South Dakota: University of South Dakota; U. of Nebraska: University of Nebraska; state name abbreviations as per US postal service.

TABle 2: Monthly average maximum, minimum, and mean temperatures $\left({ }^{\circ} \mathrm{C}\right)$ and precipitation ( $\left.\mathrm{mm}\right)$ at Brandon, MB and Swift Current, SK, Canada from 1994 to 1996 and the 30-year (1971 to 2000) means (Environment Canada 2009).

\begin{tabular}{|c|c|c|c|c|c|c|c|c|}
\hline \multirow{2}{*}{ Month } & \multicolumn{4}{|c|}{ Brandon } & \multicolumn{4}{|c|}{ Swift Current } \\
\hline & $T_{\max }$ & $T_{\min }$ & $T_{\text {mean }}$ & Precip. & $T_{\max }$ & $T_{\min }$ & $T_{\text {mean }}$ & Precip. \\
\hline & \multicolumn{8}{|c|}{ 1971-2000 mean } \\
\hline May & 19.2 & 4.4 & 11.8 & 52.6 & 17.6 & 4.5 & 11.1 & 49.5 \\
\hline June & 23.5 & 9.8 & 16.6 & 75.7 & 22 & 9.2 & 15.6 & 66 \\
\hline July & 25.9 & 11.9 & 18.9 & 72.5 & 24.8 & 11.3 & 18.1 & 52 \\
\hline Aug. & 25.4 & 10.5 & 18 & 69.2 & 25 & 10.8 & 17.9 & 39.9 \\
\hline \multirow[t]{2}{*}{ Sept. } & 18.8 & 4.9 & 11.9 & 48.3 & 18.3 & 5.3 & 11.8 & 30.2 \\
\hline & \multicolumn{8}{|c|}{1994} \\
\hline May & 19.6 & 3.4 & 11.6 & 48.2 & 18 & 5 & 11.5 & 62.4 \\
\hline June & 22.2 & 9.4 & 15.9 & 75.7 & 20.8 & 8.8 & 14.8 & 89.2 \\
\hline July & 23.9 & 10.1 & 17 & 47.2 & 25.6 & 10.6 & 18.1 & 22.4 \\
\hline Aug. & 22.9 & 9 & 16 & 30.8 & 24.8 & 10.3 & 17.6 & 23.2 \\
\hline \multirow[t]{2}{*}{ Sept. } & 21.6 & 5.4 & 13.6 & 52.6 & 22.5 & 7.5 & 15 & 10.9 \\
\hline & \multicolumn{8}{|c|}{1995} \\
\hline May & 16.8 & 3 & 9.9 & 56.4 & 16.2 & 3.2 & 9.7 & 29 \\
\hline June & 25.2 & 11.6 & 18.5 & 77.7 & 22.8 & 9.9 & 16.4 & 101 \\
\hline July & 25.1 & 11.7 & 18.4 & 25.2 & 23.6 & 11.2 & 17.4 & 57.1 \\
\hline Aug. & 26.2 & 10.6 & 18.4 & 24.6 & 23 & 10.3 & 16.7 & 107.6 \\
\hline \multirow[t]{2}{*}{ Sept. } & 19.8 & 3.3 & 11.6 & 31.8 & 18.3 & 5.5 & 11.9 & 52.8 \\
\hline & \multicolumn{8}{|c|}{1996} \\
\hline May & 14.6 & 1.7 & 8.2 & 86.8 & 13.2 & 2.4 & 7.8 & 65 \\
\hline June & 23.6 & 10.8 & 17.1 & 41 & 21.7 & 10 & 15.9 & 77.7 \\
\hline July & 24.4 & 11.3 & 17.9 & 62 & 24.3 & 11.1 & 17.7 & 23.1 \\
\hline August & 26.7 & 10.4 & 18.5 & 22.4 & 27.3 & 11.6 & 19.5 & 32.6 \\
\hline Sept. & 18 & 5.2 & 11.6 & 57.8 & 15.3 & 5.3 & 10.3 & 105.7 \\
\hline
\end{tabular}


and nutritive value parameters were analyzed based on means over years within each site. Pearson correlation coefficients were calculated with the multivariate option of JMP.

\section{Results and Discussion}

3.1. Weather. Growing season monthly temperatures from 1994 to 1996 were close to the 1971-2000 period averages [21]. Mean temperature in May was below average, especially in 1996 at both Brandon and Swift Current. Spring growth of switchgrass was not observed until June, which may be related to the cool temperatures in May at these locations. Maximum temperatures at both locations were also near the 30 -year mean for each month. The winter temperatures in 1994-95 were very cold (data not shown) with extremely low temperatures for an extended period in February and March.

On average, monthly precipitation is distributed more evenly during the growing season at Brandon compared to Swift Current which has peak rainfall in June followed by drier summer months (Table 2). During this study, the variation in monthly precipitation was greater at Swift Current which is typical of this semiarid prairie location. In 1994 at Swift Current, a wetter than normal May and June periods were followed by a drier summer. In 1995, a drier May was followed by a wetter June-to-September period. In 1996, a normal spring was followed by a drier period in July and August and then a wetter than normal September.

3.2. Stand Establishment and Persistence. Seedling emergence in all plots with the exception of Blackwell switchgrass were rated as excellent. Stand establishment at Swift Currentdryland was generally adequate in 1994 with Dacotah, ND 3743, and Summer exhibiting $>50 \%$ stands (Table 3 ). Blackwell switchgrass establishment was significantly lower than other cultivars, $13 \%$ in 1994 at Swift Current $(P<0.05)$. By the next year, however, stand density of most cultivars was not significantly different from zero. Only Dacotah and ND 3743 maintained $>50 \%$ stand density at this site in 1995. There was subsequent invasion by crested wheatgrass (Agropyron cristatum L. Gaertn.) in the cultivars where the switchgrass plant density had declined. This cool-season grass species had been grown on the site prior to this trial and residual seed in the soil may have persisted despite tillage and herbicide control prior to and subsequent to seeding switchgrass. As a result, this site was abandoned for further data collection.

At Swift Current-irrigation, all cultivars except Blackwell had adequate establishment in 1993, the year of seeding (Table 3). By 1994, Blackwell, Cave-in-Rock, Pathfinder, Summer, and Trailblazer plants density had declined significantly $(P<0.05)$. In contrast, stand density of Dacotah, Forestburg, Nebraska 28, and ND 3743 increased from 1993 to 1994 . Because stand density was recorded as a percentage of ground cover, the increase in stand density was likely due to tillering by established plants. Then by 1996, stands had declined, most below 50\% levels. Only Dacotah, Forestburg, and ND 3743 stands were maintained until 1996 at this site. Plant density decline in switchgrass is generally attributed to low-temperature injury during the winter period [22]. There was period of below normal temperatures at Swift Current during January $\left(-22.1^{\circ} \mathrm{C}\right.$; 46-year mean is -17.4$)$ and March $1996\left(-12.3^{\circ} \mathrm{C}\right.$; 46-year mean is -8.3$)$ and drier summer months at Brandon and Swift Current in 1995 and this weather may have contributed to the plant density decline in 1995-96.

Stand density data after establishment at Brandon indicated that all stands were complete $(100 \%)$ by 1994 or one year after seeding (data not shown). By the second year after seeding, however, Blackwell, Cave-in-Rock, Pathfinder, and Trailblazer stands had decreased $(P<0.05)$ at Brandon (Table 3). Dacotah, Forestbury, Nebraska 28, Summer, Sunburst, and ND 3743 switchgrasses maintained stand density in 1995 and showed little or no decline in stand density in 1996. Dacotah (98\%) and ND 3743 switchgrasses (92\%), in particular, maintained nearly complete stands in 1996. Likewise, Dacotah and ND 3743 switchgrass cultivars exhibited the best persistence among eight cultivars or experimental strains grown at three sites in western North Dakota [4]. Cave-in-Rock and Summer switchgrass exhibited stand density decline in western North Dakota [4] similar to our results, while Trailblazer was persistent in their study [4] unlike to the current study. In contrast, others reported no stand decline for Blackwell, Trailblazer, or Cave-in-Rock switchgrass over several years and several sites in North Dakota, South Dakota, and Minnesota [5]. Researchers concluded that switchgrass cultivars cannot be moved more than $500 \mathrm{~km}$ (or $5^{\circ}$ latitude) north of their geographic origin or they suffer from winter injury [4, 23]. Nevertheless, latitudinal adaptation of switchgrass would permit moves up to 2 USDA hardiness zones or about $450 \mathrm{~km}$ with no impact on stand longevity [24]. Dacotah originated approximately $300 \mathrm{~km}$ south of Brandon, while ND 3743 originated $135 \mathrm{~km}$ south of Brandon, Manitoba. Forestburg originated about $680 \mathrm{~km}$ south of Brandon, and it exhibited a decline in plant density by 1996 at Swift Current, but had excellent persistence at Brandon. Sunburst originated about $800 \mathrm{~km}$ south of Brandon and exhibited persistence comparable to Forestburg. Other cultivars in this trial originated from sites further south (Table 1) and exhibited poor persistence either at Swift Current-dryland or at both Brandon and Swift Current-irrigated sites. Our results were consistent with others [24] in that a latitudinal adaptation among switchgrass cultivars limits the distance that any cultivar can be moved northward. Casler et al. [22] also reported that southern-adapted cultivars exhibited a lack of persistence when grown at northern locations and similarly northern-adapted cultivars exhibited stand decline in southern locations. These researchers concluded that switchgrass cultivars will be needed for each region to maximize biomass for bioenergy production [22]. It can be surmised from the results from the current study that the utilization of American switchgrass cultivars in western Canada should be restricted to the most northerly adapted cultivars in order to avoid plant stand decline. 
3.3. Biomass Production. Biomass production was sensitive to higher-order interactions of location, year, and cultivar effects when the biomass production parameter was analyzed. However, when the transformed data were analyzed, only the location $\times$ cultivar interaction was significant as well as cultivar and location main effects. Cultivar $\times$ environment interactions for switchgrass have been reported for biomass production and other agronomic or biofuel traits in north central USA $[22,25]$. Location, year, and cultivar interactions were significant in this study, but the effect of harvest date was not [25]. There was also evidence of longitudinal adaptation to locations in this study related with the longitude of the original collection site for the cultivar. In contrast, others concluded that switchgrass did not exhibit adaptive response to longitude [22].

Biomass production was affected by stand density as evidenced by the high correlation between stand density and biomass production in 1996 at both Swift Current $(R=0.93$, $P<0.01)$ and at Brandon $(R=0.89, P<0.01)$ (Table 7$)$. There were significant biomass production differences $(P<0.05)$ among the cultivars in all three years at Swift Current and both years at Brandon (Table 4). Cultivar ranking changed from year to year, but Dacotah, Forestburg, Nebraska 28, and ND 3743 switchgrasses were higher yielding cultivars than Cave-in-Rock, Pathfinder, or Trailblazer. It has been observed in North Dakota that southern-adapted cultivars tend to produce more biomass than northern-adapted cultivars [4, $5]$. The biomass production observed in the present study were 28 to $40 \%$ or 60 to $72 \%$ lower than those reported in North Dakota $[4,5]$, which may be related to drier summer observed at the study locations, especially in Brandon, MB. In addition, these biomass observations are lower than coolseason perennial native grass species in this region of Western Canada [7] and suggest that switchgrass is not competitive with those species as a potential biomass for biofuel crop [8]. The biomass results of the current study confirm that southern-adapted switchgrass cultivars produce higher biomass than northern-adapted cultivars until they suffer significant stand decline with their biomass productivity declining sharply. Especially, this trend could be seen in Nebraska 28 stand density and yield changes from 1994 to 1996 at Swift Current-irrigation.

Biomass production of switchgrass at Brookings South Dakota was highly correlated with tiller density, number of phytomers per tiller, and mass per phytomer [26]. Highyielding cultivars in Wisconsin and South Dakota, such as Cave-in-Rock, had larger tillers with more and larger phytomers than early maturing and lower yielding cultivars, such as Dacotah. Biomass production differences between sites are attributed to variation in reproductive tiller density because reproductive tiller mass was five times greater than that of vegetative tillers [26]. Although these variables were not determined in the current study, we observed that southern-adapted cultivars neither maintained tiller density over time (lack of persistence discussed above) nor developed the height reported for this species in the mid-west USA locations. This suggests that low phytomer and tiller mass and possibly low reproductive tiller numbers were limiting biomass production in these southern-adapted cultivars.
3.4. Cellulose Concentration. Cellulose concentration was highest for Dacotah at Swift Current and for ND 3742 switchgrass at Brandon $(P<0.05)$ (Table 5). Cave-in-Rock exhibited the lowest cellulose concentration at both locations $(P<0.05)$. There was no significant difference among the switchgrass cultivars for hemicellulose concentration at Swift Current $(P>0.05)$. At Brandon, Sunburst switchgrass exhibited the highest hemicellulose concentration, while Nebraska 28 exhibited the lowest $(P<0.05)$. Dacotah and ND 3743 contained the highest neutral detergent fiber (NDF) concentrations at both sites while Cave-in-Rock had the lowest $(P<0.05)$ (Table 6). The NDF concentration is a prediction of forage intake by ruminants [27], so these results suggest that northern-adapted switchgrass cultivars would be consumed less by beef cattle than southern-adapted cultivars.

Cave-in-Rock switchgrass exhibited the highest organic matter digestibility (OMD) while Dacotah switchgrass had the lowest OMD at both locations $(P<0.05)$ (Table 6). As well, Cave-in-Rock switchgrass was the highest in $\mathrm{N}$ concentration at both sites $(P<0.05)$. Dacotah switchgrass meanwhile had the lowest $\mathrm{N}$ concentration at Swift Current, while Dacotah and ND 3743 had the lowest N concentrations at Brandon $(P<0.05)$. There was no significant difference in $\mathrm{P}$ concentration among switchgrass cultivars at Swift Current $(P>0.05)$. At Brandon, highest $\mathrm{P}$ concentration was found in Cave-in-Rock switchgrass, whereas the lowest $\mathrm{P}$ concentration was in Dacotah and ND $3743(P<0.05)$. All the observed $\mathrm{P}$ concentrations were greater than the $1.0 \mathrm{~g} \mathrm{~kg}^{-1}$ required for beef cattle diets [28]. Furthermore, Dacotah and ND 3743 exhibited the highest Ca concentrations (Table 5), while either Cave-in-Rock (Swift Current) or Sunburst (Brandon) had the lowest $(P<0.05)$. Only Dacotah and ND 3743 exhibited sufficient Ca concentration to satisfy the requirement of beef cattle at a minimum of $6.0 \mathrm{~g} \mathrm{~kg}^{-1}$ level [28]. Forage from all other switchgrass cultivars would require mineral supplementation to avoid $\mathrm{Ca}$ deficiency.

3.5. Relationship to Latitude. Variation in latitude of origin was positively correlated with stand density and cellulose concentration but negatively correlated with OMD digestibility and $\mathrm{N}$ concentration. Correlation between latitude of origin and biomass production, $\mathrm{P}$ concentration, or Ca concentration depended on the location. The correlation between latitude of origin and plant density in 1996 differed between Brandon and Swift Current (Figure 1). Several cultivars that exhibited mediocre stand density at Brandon did not persist at Swift Current. A generally linear relationship of switchgrass yield with latitude was found in south central US environments [2]. Cultivars from higher latitude of origin in USA, such as Dacotah and ND 3743 had greater plant density, cellulose, and Ca concentrations, but lower OMD, N, and P concentrations than cultivars from southern latitudes. This suggests that plant breeders will need to select switchgrass cultivars for adaptation at northern latitudes to improve feed-stock availability for ligno-cellulosic production and conversion to biofuels. Similarly, other studies concluded that regional cultivars of switchgrass, rather than broadly adapted cultivars, will 
TABLE 3: Stand density (\%) of ten switchgrass cultivars at Swift Current, SK and Brandon, MB, Canada.

\begin{tabular}{|c|c|c|c|c|c|c|c|}
\hline \multirow[t]{2}{*}{ Cultivar } & \multicolumn{2}{|c|}{ Dryland } & \multirow{2}{*}{$\begin{array}{c}\text { Swift Current } \\
1993 \\
\end{array}$} & \multirow{2}{*}{$\begin{array}{c}\text { Irrigation } \\
1994\end{array}$} & \multirow[b]{2}{*}{1996} & \multicolumn{2}{|c|}{ Brandon } \\
\hline & 1994 & 1995 & & & & 1995 & 1996 \\
\hline Blackwell & 13 & 0 & 5 & 0 & 3 & 20 & 29 \\
\hline Cave-in-Rock & 42 & 0 & 41 & 0 & 1 & 27 & 10 \\
\hline Dacotah & 59 & 51 & 43 & 81 & 89 & 99 & 100 \\
\hline Forestburg & 36 & 15 & 43 & 57 & 44 & 99 & 89 \\
\hline Nebraska 28 & 49 & 14 & 32 & 55 & 15 & 99 & 91 \\
\hline Pathfinder & 41 & 0 & 48 & 0 & 1 & 57 & 49 \\
\hline Summer & 51 & 2 & 48 & 12 & 1 & 96 & 86 \\
\hline Sunburst & 45 & 1 & 33 & 37 & 23 & 87 & 82 \\
\hline ND 3743 & 53 & 56 & 40 & 69 & 58 & 100 & 94 \\
\hline Trailblazer & 40 & 1 & 32 & 0 & 1 & 37 & 27 \\
\hline $\mathrm{LSD}_{0.05}$ & 16 & 20 & 15 & 19 & 18 & 25 & 10 \\
\hline
\end{tabular}

TABLE 4: Mean biomass production of ten switchgrass cultivars grown at Swift Current-irrigated, SK and at Brandon, MB, Canada.

\begin{tabular}{|c|c|c|c|c|c|}
\hline \multirow{2}{*}{ Cultivar $^{\wedge}$} & \multicolumn{3}{|c|}{ Swift Current } & \multicolumn{2}{|c|}{ Brandon } \\
\hline & 1994 & 1995 & 1996 & 1995 & 1996 \\
\hline & \multicolumn{5}{|c|}{$\mathrm{Mg} \mathrm{ha}^{-1}$} \\
\hline Blackwell & 0.03 & 0.68 & 1.19 & 1.42 & 0.21 \\
\hline Cave-in-Rock & 0.03 & 0.37 & 0.07 & 0.96 & 0.07 \\
\hline Dacotah & 1.19 & 7.63 & 9.41 & 3.53 & 0.98 \\
\hline Forestburg & 0.88 & 9.22 & 3.95 & 4.12 & 0.89 \\
\hline Nebraska 28 & 0.80 & 9.45 & 0.91 & 3.67 & 0.52 \\
\hline Pathfinder & 0.04 & 0.55 & 0.27 & 2.55 & 0.52 \\
\hline Summer & 0.13 & 1.28 & 0.12 & 3.73 & 0.85 \\
\hline Sunburst & 0.35 & 4.71 & 1.03 & 3.81 & 1.14 \\
\hline ND 3743 & 0.50 & 5.38 & 2.79 & 3.09 & 0.89 \\
\hline Trailblazer & 0.00 & 0.30 & 0.17 & 1.04 & 0.23 \\
\hline $\mathrm{LSD}_{0.05}$ & 0.36 & 1.26 & 2.40 & 1.50 & 0.36 \\
\hline
\end{tabular}

${ }^{\wedge}$ Mean values were backtransformed to the original data scale after analysis of variance on $\log _{10}$ transformed values. Probability of the cultivar effect was determined from transformed data analysis of variance. LSD values were calculated from analysis of variance error term of original scale data.

TABLE 5: Mean cellulose and hemicellulose concentration of ten switchgrass cultivars grown at Swift Current, SK and at Brandon, MB, Canada.

\begin{tabular}{|c|c|c|c|c|}
\hline \multirow{2}{*}{ Cultivar } & \multicolumn{2}{|c|}{ Cellulose } & \multicolumn{2}{|c|}{ Hemicellulose } \\
\hline & Swift Current & Brandon & Swift Current & Brandon \\
\hline & \multicolumn{4}{|c|}{$\mathrm{g} \mathrm{kg}^{-1}$} \\
\hline Blackwell & 282 & 288 & 288 & 266 \\
\hline Cave-in-Rock & 249 & 283 & 285 & 266 \\
\hline Dacotah & 312 & 330 & 293 & 275 \\
\hline Forestburg & 306 & 298 & 300 & 296 \\
\hline Nebraska 28 & 307 & 294 & 300 & 262 \\
\hline Pathfinder & 274 & 290 & 284 & 274 \\
\hline Summer & 285 & 311 & 301 & 288 \\
\hline Sunburst & 293 & 313 & 302 & 302 \\
\hline ND 3743 & 306 & 342 & 289 & 291 \\
\hline Trailblazer & - & 285 & - & 270 \\
\hline $\mathrm{LSD}_{0.05}$ & 10 & 12 & $\mathrm{~ns}$ & 16 \\
\hline
\end{tabular}

ns: not significant at $P=0.05$. 
TABle 6: Mean organic matter digestibility (OMD), neutral detergent fiber (NDF), N, P, and Ca concentration of ten switchgrass cultivars grown at Swift Current, SK and at Brandon, MB, Canada.

\begin{tabular}{|c|c|c|c|c|c|c|c|c|c|c|}
\hline \multirow{2}{*}{ Cultivar } & \multicolumn{2}{|c|}{ OMD } & \multicolumn{2}{|l|}{$\mathrm{N}$} & \multicolumn{2}{|l|}{$\mathrm{P}$} & \multicolumn{2}{|c|}{ NDF } & \multicolumn{2}{|l|}{$\mathrm{Ca}$} \\
\hline & Swift Current & Brandon & Swift Current & Brandon & Swift Current & Brandon & Swift Current & Brandon & Swift Current & Brandon \\
\hline & \multicolumn{10}{|c|}{$\mathrm{g} \mathrm{kg}^{-1}$} \\
\hline Blackwell & 579 & 549 & 18 & 11 & 2.3 & 2.3 & 588 & 559 & 4.55 & 5.27 \\
\hline Cave-in-Rock & 612 & 563 & 21 & 13 & 2.2 & 2.6 & 537 & 551 & 3.74 & 5.49 \\
\hline Dacotah & 521 & 443 & 12 & 6 & 2.7 & 1.5 & 629 & 612 & 6.05 & 7.05 \\
\hline Forestburg & 524 & 503 & 15 & 8 & 2.4 & 1.9 & 621 & 602 & 4.62 & 5.64 \\
\hline Nebraska 28 & 527 & 507 & 15 & 8 & 2.5 & 1.9 & 624 & 558 & 4.26 & 5.93 \\
\hline Pathfinder & 590 & 534 & 21 & 10 & 2.7 & 2.1 & 579 & 565 & 4.38 & 5.40 \\
\hline Summer & 562 & 499 & 17 & 8 & 2.4 & 2.0 & 592 & 603 & 4.30 & 5.93 \\
\hline Sunburst & 546 & 490 & 16 & 7 & 2.2 & 1.6 & 612 & 621 & 3.97 & 4.60 \\
\hline ND 3743 & 537 & 446 & 14 & 6 & 2.6 & 1.5 & 616 & 647 & 6.13 & 6.22 \\
\hline Trailblazer & - & 560 & - & 12 & - & 2.5 & - & 557 & 5.42 & 5.73 \\
\hline $\mathrm{LSD}_{0.05}$ & 13 & 24 & 1 & 1 & $\mathrm{~ns}$ & 0.4 & 13 & 14 & 0.43 & 0.73 \\
\hline
\end{tabular}

ns: not significant at $P=0.05$.

TABLE 7: Pearson correlation coefficients for mean values of traits of 10 switchgrass cultivars at Brandon, MB (above the diagonal) and at Swift Current, SK (below the diagonal), Canada.

\begin{tabular}{lccccccccc}
\hline Trait & Latitude & Stand & Yield & Cellulose & Hemicellulose & OMD & $\mathrm{N}$ & $\mathrm{P}$ \\
\hline Latitude & - & $0.83^{* *}$ & $0.78^{* *}$ & $0.89^{* *}$ & 0.57 & $-0.92^{* *}$ & $-0.88^{* *}$ & $-0.88^{* *}$ & 0.52 \\
Stand & $0.83^{* *}$ & - & $0.89^{* *}$ & $0.75^{* *}$ & 0.56 & $-0.90^{* *}$ & $-0.97^{* *}$ & $-0.91^{* *}$ & 0.43 \\
Yield & 0.60 & $0.93^{* *}$ & - & $0.77^{* *}$ & $0.82^{* *}$ & $-0.86^{* *}$ & $-0.92^{* *}$ & $-0.91^{* *}$ & 0.17 \\
Cellulose & $0.80^{* *}$ & $0.73^{*}$ & $0.63^{*}$ & - & 0.55 & $-0.96^{* *}$ & $-0.87^{* *}$ & $-0.88^{* *}$ & 0.51 \\
Hemicellulose & 0.30 & 0.13 & 0.07 & 0.56 & - & -0.53 & -0.60 & -0.60 & -0.22 \\
OMD & $-0.80^{* *}$ & $-0.73^{*}$ & $-0.63^{*}$ & $-0.98^{* *}$ & $-0.66^{*}$ & - & $0.96^{* *}$ & $0.96^{* *}$ & -0.55 \\
$\mathrm{~N}$ & $-0.82^{* *}$ & $-0.84^{* *}$ & $-0.75^{* *}$ & $-0.93^{* *}$ & -0.53 & $0.94^{* *}$ & - & $0.98^{* *}$ & -0.34 \\
$\mathrm{P}$ & 0.53 & 0.50 & 0.50 & 0.47 & -0.24 & -0.36 & -0.34 & - & -0.34 \\
$\mathrm{Ca}$ & $0.78^{* *}$ & $0.85^{* *}$ & $0.76^{* *}$ & $0.64^{*}$ & -0.15 & -0.56 & $-0.70^{*}$ & $0.69^{*}$ & - \\
\hline
\end{tabular}

$*, * *$ correlation coefficient is significant at $P<0.05$ and $P<0.01$, respectively.

be needed for biomass production for biofuel conversion [22]. However, if switchgrass cultivars are required for grazing, then improved forage quality could be selected by incorporating genetic sources from southern latitudes that will have later maturity and higher forage quality. Our results support others' conclusions $[22,24]$ that latitude of origin influences switchgrass longevity and cellulose concentration and this effect of latitude is more important at the limits of a cultivar's adaptation. Swift Current and Brandon represent the most northern environments where some of these switchgrass cultivars have been tested.

Variation in stand density among the cultivars was positively correlated with biomass production, cellulose concentration, and $\mathrm{Ca}$ concentration but negatively correlated with OMD and N concentrations (Table 7). Dacotah and ND 3743 switchgrasses were more persistent and exhibited the highest cellulose concentrations but had the lowest OMD and $\mathrm{N}$ concentrations $(P<0.05)$. Blackwell, Cave-in-Rock, and Trailblazer switchgrass were less persistent and had the lowest cellulose concentrations and the highest OMD and $\mathrm{N}$ concentrations $(P<0.05)$. Cellulose concentration was correlated with latitude of cultivar origin similarly at Swift Current and Brandon (Figure 2).

Biomass production was correlated with cellulose (Table 7). Biomass production was greater in earlier maturing, northern-adapted cultivars such as Dacotah and ND 3743. As others have stated, biomass production is correlated with a larger proportion reproductive tillers that have large and numerous phytomers $[22,26]$. In the present study, southern-adapted cultivars tended to remain vegetative in the two study sites due to the shorter growing season.

As expected, cellulose concentration was negatively correlated with OMD, N, and Ca concentrations, but at Swift Current only (Table 7). Hemicellulose concentration was also negatively correlated with OMD concentration at Swift Current. Meanwhile, OMD was positively correlated with cultivar differences in $\mathrm{N}$ concentration (Table 7). Nitrogen concentration was positively correlated with $\mathrm{P}$ concentration at Brandon as has been reported for other grasses such as timothy (Phleum pratense L.) [29]. The relationship between latitude of origin and OMD digestibility differed between Brandon and Swift Current (Figure 3). Finally, the current 


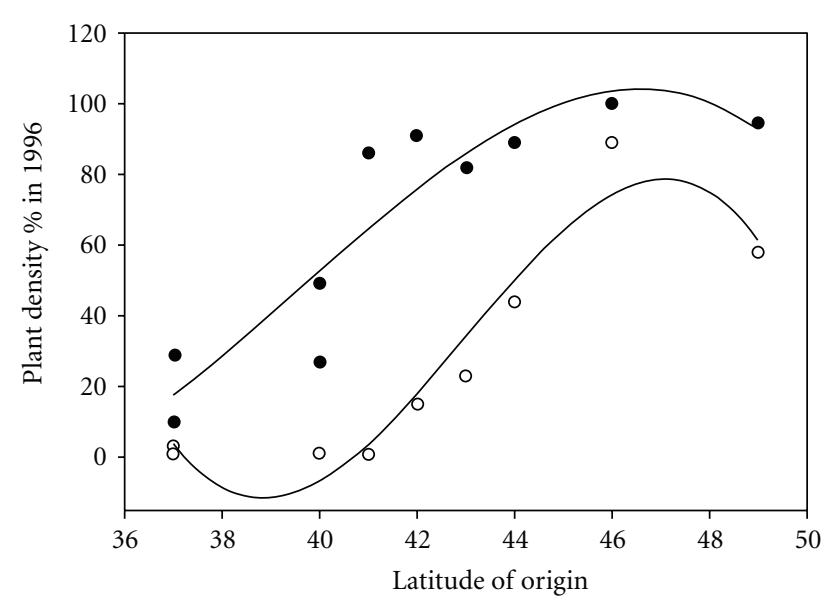

- Brandon

- Swift Current

FIGURE 1: Effect of latitude of origin for 10 switchgrass cultivars on plant density in 1996 at two locations in the southern prairie region of western Canada. The cubic regressions are significant at Brandon $\left(P<0.01, R^{2}=0.76\right)$ and at Swift Current $\left(P<0.001, R^{2}=0.90\right)$.

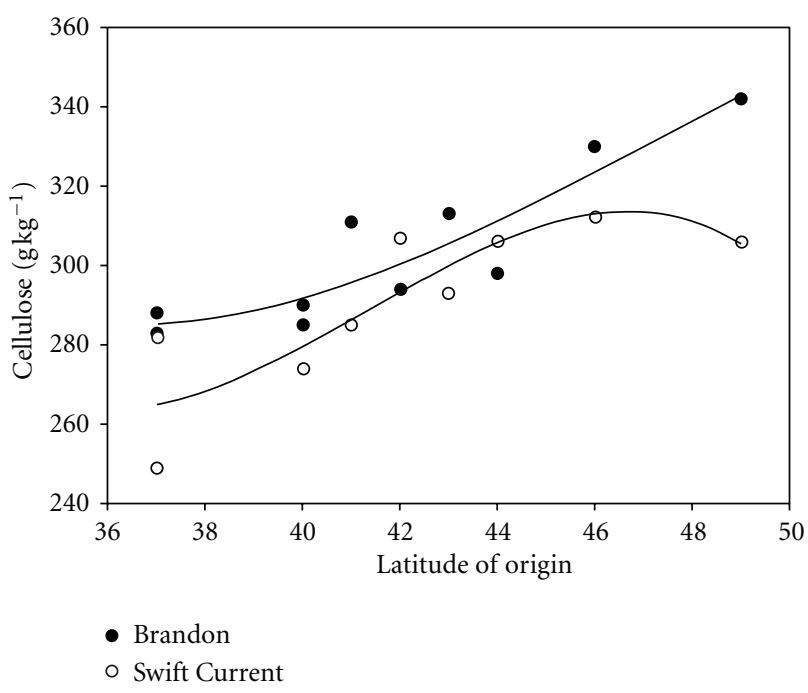

FIGURE 2: Effect of latitude of origin for 10 switchgrass cultivars on mean cellulose concentration at two locations in the southern prairie region of western Canada. The cubic regressions are significant at Brandon, $\mathrm{MB},\left(P<0.01, R^{2}=0.75\right)$ and nearly significant at Swift Current, SK, $\left(P<0.06, R^{2}=0.61\right)$, Canada. $\mathrm{Y}, \mathrm{g} \mathrm{kg}^{-1}=334.3-3.61 X$

study indicated that Dacotah and ND 3743 switchgrasses were more mature and lower in OMD at Brandon than at Swift Current.

The regression results in Figures 1-3 indicate that different responses were evident at Swift Current and Brandon despite their similarity in latitude $\left(50^{\circ} 16^{\prime}\right.$ versus $49^{\circ} 50^{\prime}$, resp.). However, elevation also contributes to climatic conditions and Swift Current is $416 \mathrm{~m}$ higher than Brandon. If the correlation to latitude is adjusted to account for the elevational difference between the two testing sites, then site

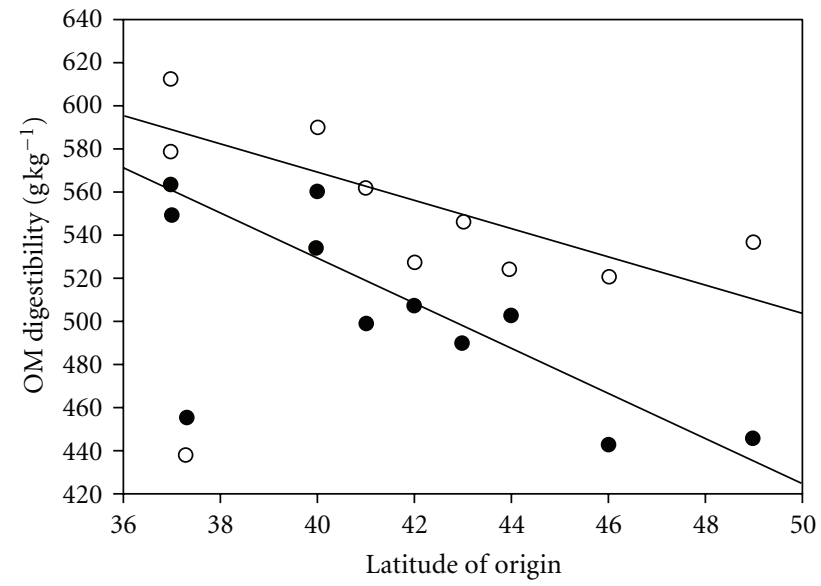

- Brandon

- Swift Current

FIGURE 3: Effect of latitude of origin for 10 switchgrass cultivars on organic matter digestibility (OMD) concentration at two locations in the southern prairie region of western Canada. The linear regressions are significant at Brandon, $\mathrm{MB},\left(P<0.001, R^{2}=0.83\right)$ and at Swift Current, SK, $\left(P<0.001, R^{2}=0.83\right)$, Canada. $Y, \mathrm{~g} \mathrm{~kg}^{-1}$ $=437.6+7.8 X$.

differences are removed and one regression equation can explain the results from both sites (data not shown).

\section{Conclusions}

Switchgrass cultivation will be more successful in Manitoba and possibly southeastern Saskatchewan which border on the tallgrass prairie. Further west in the mixed grass prairie region typified by Swift Current, switchgrass productivity will be limited by winter temperatures. There may be a longitudinal adaptation required for successful cultivation of this species in the mixed prairie region but as the current study revealed it is highly related to latitudinal adaptation. Only switchgrass cultivars from northern latitudes in USA possess sufficient hardiness to be successfully cultivated on the southern Canadian prairies. Sustainable Canadian switchgrass biomass production will require the development of cultivars adapted to Canadian conditions that would exhibit superior stand longevity such as that exhibited by northernadapted cultivars in North Dakota. Cellulose concentration for switchgrass biomass conversion to ethanol was highest in the most northern-adapted cultivars likely because they had progressed further in phenological development. Cellulose production per hectare will be a function of both yield and cellulose concentration, so plant breeding to develop Canadian cultivars for energy production should focus on earlier maturity germplasm. The higher OMD observed for cultivars from southern latitudes (Figure 3) indicated that plant breeding for a potential grazing cultivar of switchgrass would favour the use of germplasm from southern-adapted cultivars. 


\section{References}

[1] M. A. Sanderson, P. R. Adler, A. A. Boateng, M. D. Casler, and G. Sarath, "Switchgrass as a biofuels feedstock in the USA," Canadian Journal of Plant Science, vol. 86, no. 5, pp. 1315$1325,2006$.

[2] J. Kaiser and S. Bruckerhoff, "Switchgrass for biomass production by variety selection and establishment methods for Missouri, Illinois, and Iowa," Agronomy Technical Note 35, 2009.

[3] K. A. Cassida, J. P. Muir, M. A. Hussey, J. C. Read, B. C. Venuto, and W. R. Ocumpaugh, "Biomass yield and stand characteristics of switchgrass in south central U.S. environments," Crop Science, vol. 45, no. 2, pp. 673-681, 2005.

[4] J. D. Berdahl, A. B. Frank, J. M. Krupinsky, P. M. Carr, J. D. Hanson, and H. A. Johnson, "Biomass yield, phenology, and survival of diverse switchgrass cultivars and experimental strains in western North Dakota," Agronomy Journal, vol. 97, no. 2, pp. 549-555, 2005.

[5] D. A. Tober, W. Kuckwitz, N. Jensen, and M. Knudson, Switchgrass Biomass Trials in North Dakota, South Dakota, and Minnesota, United States Department of Agriculture, Natural Resources Conservation Service, Plant Materials Center, Bismarck, ND, USA, 2007.

[6] I. C. Madakadze, K. Stewart, P. R. Peterson, B. E. Coulman, and D. L. Smith, "Switchgrass biomass and chemical composition for biofuel in eastern Canada," Agronomy Journal, vol. 91, no. 4, pp. 696-701, 1999.

[7] P. G. Jefferson, W. P. McCaughey, K. May, J. Woosaree, L. McFarlane, and S. M. B. Wright, "Performance of American native grass cultivars in the Canadian prairie provinces," Native Plants Journal, vol. 3, pp. 24-33, 2002.

[8] P. G. Jefferson, W. P. McCaughey, K. May, J. Woosaree, and L. McFarlane, "Potential utilization of native prairie grasses from western Canada as ethanol feedstock," Canadian Journal of Plant Science, vol. 84, no. 4, pp. 1067-1075, 2004.

[9] K. N. Ayres, D. R. Acton, and J. G. Ellis, The Soils of the Swift Current Map Area (72 J), Saskatchewan Institute of Applied Science \& Technology Pedalingl, Saskatchewan, Canada, 1985.

[10] J. Alderson and W. C. Sharp, Grass Varieties in the United States, Agriculture Handbook 170, United States Department of Agriculture, Soil Conservation Service, 1994.

[11] R. G. D. Steel, J. H. Torrie, and D. A. Dickey, Principles and Procedures of Statistics: A Biometrical Approach, McGraw-Hill Book, New York, NY, USA, 3rd edition, 1997.

[12] E. W. Crampton and L. A. Maynard, "The relation of cellulose and lignin content to the nutritive value of animal feeds," Journal of Nutrition, vol. 15, pp. 383-395, 1938.

[13] H. K. Goering and P. J. Van Soest, Forage Fiber Analysis, Agriculture Handbook 379, Agriculture Research Service, USDA, Washington, DC, USA, 1970.

[14] J. M. A. Tilley and R. A. Terry, "A two stage technique for the in vitro digestion of forage crops," Journal of the British Grassland Society, vol. 18, pp. 104-111, 1963.

[15] J. E. Troelsen and D. J. Hanel, "Ruminant digestion in vitro as affected by inoculum donor, collection day, and fermentation time," Canadian Journal of Animal Science, vol. 46, pp. 149 $156,1966$.

[16] E. D. Olfert, B. M. Cross, and A. A. McWilliam, Guide to the Care and Use of Experimental Animals, vol. 50, Canadian Council on Animal Care, Ottawa, Canada, 2nd edition, 1993.

[17] AOAC, Official Methods of Analysis of the Association of Official Analytical Chemists, AOAC Arlington, Virginia, Va, USA, 14th edition, 1984.
[18] J. A. Varley, "Automatic methods for the determination of nitrogen, phosphorus and potassium in plant material," The Analyst, vol. 91, no. 1079, pp. 119-126, 1966.

[19] R. O. Miller, "Nitric-perchloric acid wet digestion in an open vessel," in Handbook of Reference Methods for Plant Analysis, Y. P. Kalra, Ed., pp. 57-61, CRC Press, 1998.

[20] SAS Institute, JMP Statistics and Graphics Guide. Version 3. 2, SAS Institute, Cary, NC, USA, 1995.

[21] Environment Canada. Historical weather records, Ottawa, Canada, 2009, http://www.climate.weatheroffice.ec.gc.ca/ climateData/canada_e.html

[22] M. D. Casler, K. P. Vogel, C. M. Taliaferro et al., "Latitudinal and longitudinal adaptation of switchgrass populations," Crop Science, vol. 47, no. 6, pp. 2249-2260, 2007.

[23] D. A. Tober and A. D. Chamrad, "Warm-season grasses in the Northern Great Plains," Rangelands, vol. 14, pp. 227-230, 1992.

[24] M. D. Casler, K. P. Vogel, C. M. Taliaferro, and R. L. Wynia, "Latitudinal adaptation of Switchgrass Populations," Crop Science, vol. 44, no. 1, pp. 293-303, 2004.

[25] M. D. Casler and A. R. Boe, "Cultivar x Environment interactions in switchgrass," Crop Science, vol. 43, no. 6, pp. 2226-2233, 2003.

[26] A. Boe and D. L. Beck, "Yield components of biomass in switchgrass," Crop Science, vol. 48, no. 4, pp. 1306-1311, 2008.

[27] P. J. Van Soest, Nutritional Ecology of the Ruminant, O\&B Books, Corvallis, Ore, USA, 1982.

[28] D. C. Church, Livestock Feeds and Feeding, O\&B Books, Corvallis, Ore, USA, 1977.

[29] G. Bélanger and J. E. Richards, "Relationship between P and N concentrations in timothy," Canadian Journal of Plant Science, vol. 79, no. 1, pp. 65-70, 1999. 


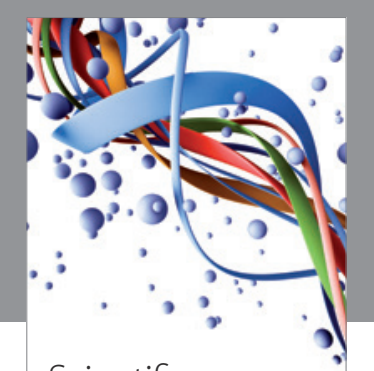

Scientifica
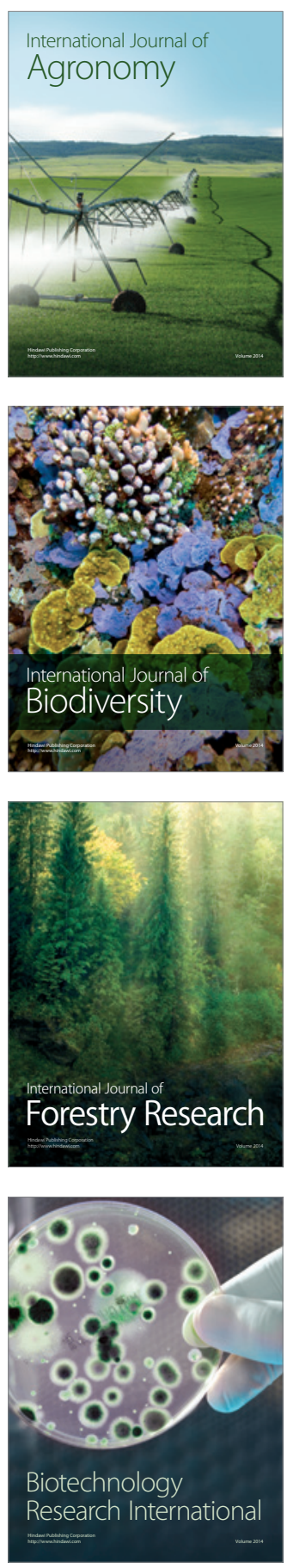
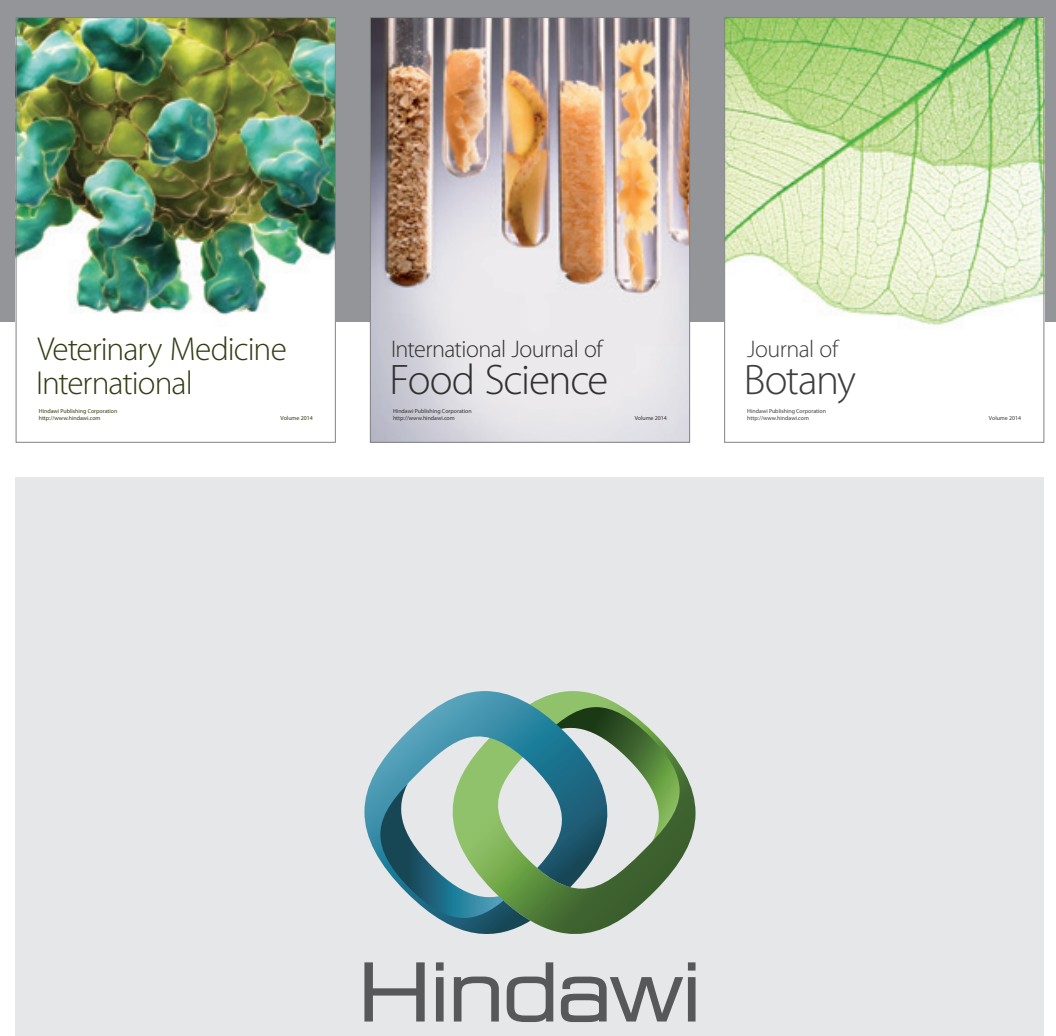

Submit your manuscripts at

http://www.hindawi.com
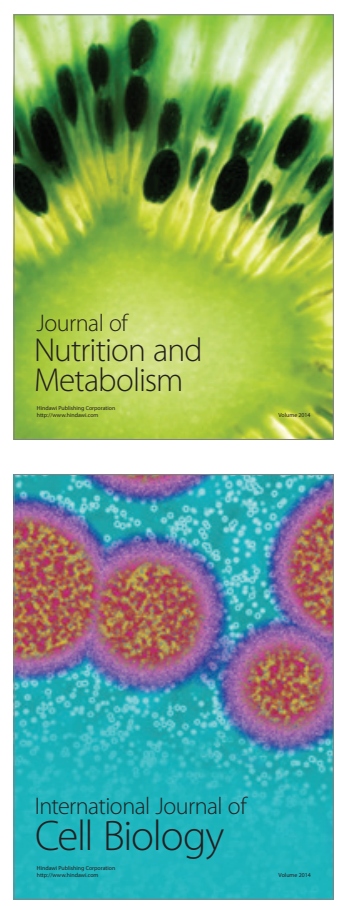
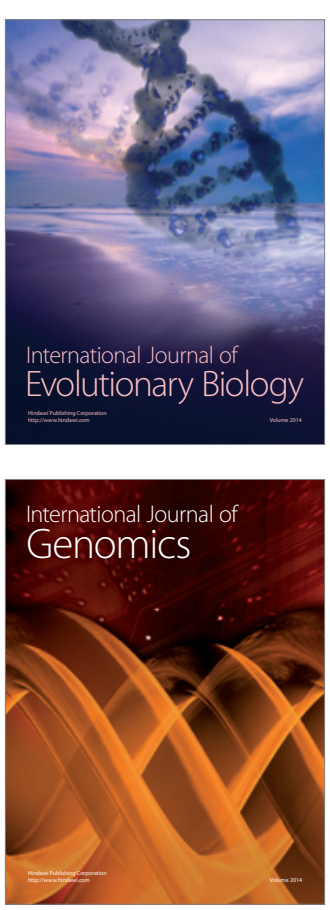
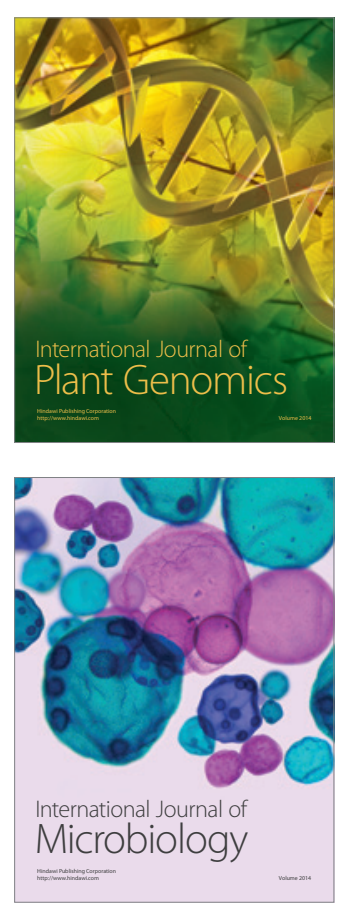

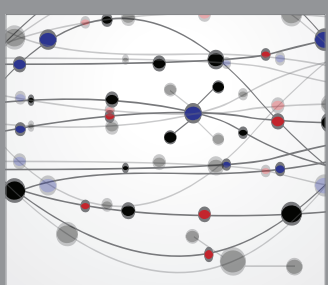

The Scientific World Journal
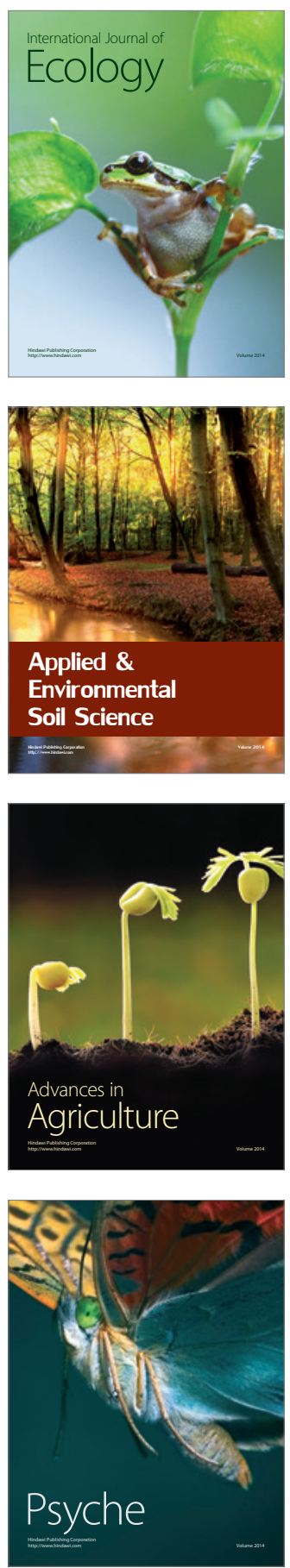